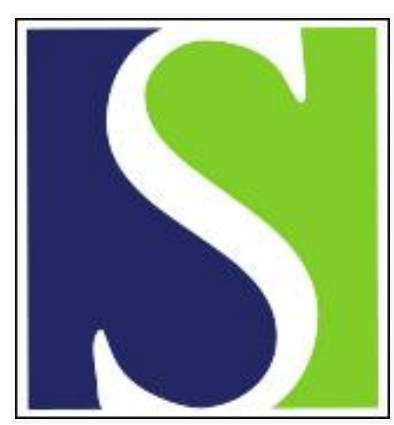

Scand J Work Environ Health 1994;20(6):417-426

https://doi.org/10.5271/sjweh.1379

Issue date: 01 Dec 1994

Job task and psychosocial risk factors for work-related musculoskeletal disorders among newspaper employees.

by Bernard B, Sauter S, Fine L, Petersen M, Hales T

Affiliation: National Institute for Occupational Safety and Health, Division of Surveillance, Hazard Evaluations, and Field Studies, Cincinnati, Ohio 45226.

This article in PubMed: www.ncbi.nlm.nih.gov/pubmed/7701287 


\title{
Job task and psychosocial risk factors for work-related musculoskeletal disorders among newspaper employees
}

\author{
by Bruce Bernard, MD, ${ }^{1}$ Steve Sauter, $\mathrm{PhD},{ }^{2}$ Lawrence Fine, MD,${ }^{1}$ Martin Petersen, $\mathrm{PhD},{ }^{1}$ \\ Thomas Hales, MD'
}

\begin{abstract}
BERNARD B, SAUTER S, FINE L, PETERSEN M, HALES T. Job task and psychosocial risk factors for work-related musculoskeletal disorders among newspaper employees. Scand $J$ Work Environ Health 1994;20:417-26.
\end{abstract}

\begin{abstract}
OrJectives - A cross-sectional study was conducted to assess the association of upper extremity musculoskeletal disorders and work-related factors among employees using video display terminals at a large metropolitan newspaper.
\end{abstract}

\begin{abstract}
METHODS - The study included 1050 randomly selected workers from four departments. The workers were asked to complete questionnaires on symptoms, job tasks, and psychosocial and work organization conditions. Musculoskeletal disorders of the upper extremities were defined by frequency, duration, and intensity of symptoms not attributable to acute injury. Data were analyzed with the use of logistic regression.

REsults - A total of 973 workers completed the survey. The one-year period prevalence rate for any musculoskeletal disorder of the upper extremities was $41 \%$. Neck symptoms $(26 \%)$ were the most frequently reported, followed by hand or wrist $(22 \%)$, shoulder $(17 \%)$, and elbow (10\%) symptoms. Greater time working at the video display station was associated with increased hand or wrist symptoms in a dose-response relationship. In addition, variables corresponding to increased work-load demands (eg, increased time working under deadline and increased job pressure) were associated with increased neck, shoulder, and hand or wrist disorders. Women were more likely to report symptoms in several areas, but this finding may reflect the concentration of women in jobs involving more risk factors.

Conclusions - The results suggest a high prevalence of musculoskeletal disorders of the upper extremities among newspaper employees, and they provide additional evidence that increased work load, time pressure, and greater hours of computer use are related to the occurrence of work-related musculoskeletal disorders among these workers, particularly for disorders in the hand or wrist area.
\end{abstract}

KEY TERMS - office automation, cumulative trauma disorders, ergonomics, psychosocial, repetitive motion disorders, video display terminals, work stress.

Computerization has altered the way newspaper employees write, edit, design, and sell newspapers. The video display terminal (VDT) provides both greater access to information and ease of information retrieval and processing, but it has also been associated with a high prevalence of musculoskeletal symptoms among newspaper employees. Several studies have reported musculoskeletal symptoms in 20 to $40 \%$ of this occupational group $(1-3)$. However, little has been written about associated risk factors. In particular, few studies have attempted to untangle the effects of suggestive putative factors such as hours of VDT work, worker demographics, work organiza-

1 National Institute for Occupational Safety and Health, Division of Surveillance, Hazard Evaluations, and Field Studies, Cincinnati, Ohio, United States.

2 National Institute for Occupational Safety and Health, Division of Biomedical and Behavioral Science, Cincinnati, Ohio, United States.

Reprint requests to: Dr B Bernard, National Institute for Occupational Safety and Health, 4676 Columbia Parkway, Mailstop R-10, Cincinnati, Ohio 45226, USA. tion, and the psychosocial environment in the newspaper workplace.

This cross-sectional study formed part of a larger investigation of work-related musculoskeletal disorders among newspaper employees with varying degrees of VDT use. This paper reports the prevalences of symptoms of work-related musculoskeletal disorders among this group and investigates the relationship of these symptoms to a variety of job conditions. The editorial staff was of special focus since previous data indicated a high rate of musculoskeletal problems among these employees $(1,2)$. Because previously collected data linked self-reported VDT exposure to musculoskeletal disorders (1), we also assessed the accuracy of self-reported VDT use by more objective job-sampling techniques.

\section{Subjects and methods}

The study population of 1050 was randomly selected from among the 3000 current full-time employees from four departments of the newspaper: editorial, 
circulation, classified advertising, and accounting. These departments were selected because the employees performed jobs with a wide range of hours of computer keyboard use, job tasks, and psychosocial and work organizational conditions for comparison purposes. The classified advertising and circulation departments consisted mainly of VDT operators who performed sales or clerical tasks, whereas the accounting department, like the editorial department, consisted of professional staff using VDT stations.

Randomly selected employees within the four chosen departments were notified of the study by mail and were asked to participate. They were also invited to participate by a letter signed by both an employee and a management ergonomic committee representative in their respective departments. Informed consent was obtained from each person prior to participation. Persons under 18 years of age and women who were currently pregnant were excluded from participation in the study.

Altogether 973 (93\%) employees were included in the resulting study sample. All four departments had well above $85 \%$ participation. These response rates suggest that a high level of interest with respect to work-related musculoskeletal disorders exists among newspaper employees. The study population characteristics are shown by department in table 1 . Over all departments, $1 \%$ were self-reported native Americans or Alaskan natives, $10 \%$ were Asian, $14 \%$ were Hispanic, $17 \%$ were African-American, $56 \%$ were of non-Hispanic European ancestry, and $2 \%$ listed themselves as "other."

\section{Questionnaire}

A self-administered questionnaire was used to obtain information on demographics, musculoskeletal symptoms of the upper extremities, job tasks, work history, work organization, and the psychosocial work environment. These questionnaire items were derived primarily from those used in previous investigations of the National Institute for Occupational Safety and Health (NIOSH) on work-related musculoskeletal disorders of the upper extremities (4-6) with modifications made after discussions with interested parties within the newspaper and the completion of pi- lot studies. Questions addressing psychosocial aspects of the work environment were taken from a separate NIOSH general job-stress instrument consisting of items which had extensive use in occupational stress research (7-9). Although information concerning workstation equipment was obtained, analyses were not performed on these variables because of changes that occurred in several departments both before and during the study period. The employees who reported symptoms were often given new furniture or equipment by the newspaper management. However, this practice was not consistent by department. Relationships of symptoms to workplace equipment were not evaluated because these changes reduced the reliability of exposure assessment. The questionnaire was administered to employees in groups of 5 to 40 in prescheduled, $1-\mathrm{h}$ periods during workhours.

\section{Health outcomes}

Information was obtained about symptoms of pain, numbness, tingling, aching, stiffness, or burning within the preceding year in specific areas of the neck and upper extremities (shoulder, elbow, hand, or wrist regions). The frequency of these symptoms during the preceding year was determined by an "anchored" five-point scale from "almost never (every 6 months)" to "almost always (daily)." The usual duration of the symptoms was ascertained with a seven-point scale of "less than 1 hour" to "more than 3 months." The intensity of the symptoms was evaluated with a five-point scale from "no pain" to "worst pain ever in life."

\section{Case definition for work-related musculoskeletal disorders}

For any of the relevant body areas (neck, shoulder, hand, or wrist), a work-related musculoskeletal disorder of the upper extremity was considered present if symptoms (pain, numbness, tingling, aching, stiffness, or burning) in the affected part occurred within the preceding year and all of the following criteria applied: (i) no previous accident or sudden injury that was not work-related (such as dislocation, sports injury, fracture, or tendon tear), (ii) symptoms

Table 1. Demographic variables of the subjects by the department in which they were employed.

\begin{tabular}{|c|c|c|c|c|c|c|c|}
\hline \multirow[t]{2}{*}{ Department } & \multicolumn{2}{|c|}{ Age } & \multirow[t]{2}{*}{$\begin{array}{c}\text { Percentage } \\
\text { of women }\end{array}$} & \multicolumn{2}{|c|}{$\begin{array}{l}\text { Length of } \\
\text { employment at } \\
\text { the newspaper }\end{array}$} & \multicolumn{2}{|c|}{$\begin{array}{l}\text { Length of } \\
\text { employment at } \\
\text { any newspaper }\end{array}$} \\
\hline & Mean & $\mathrm{SD}$ & & Mean & $\mathrm{SD}$ & Mean & SD \\
\hline $\begin{array}{l}\text { Accounting }(N=180) \\
\text { Circulation }(N=193) \\
\text { Classified }(N=171) \\
\text { Editorial }(N=429)\end{array}$ & $\begin{array}{l}39.4 \\
37.4 \\
37.1 \\
40.5\end{array}$ & $\begin{array}{r}10.5 \\
11.6 \\
10.6 \\
9.8\end{array}$ & $\begin{array}{l}6.7 \\
68 \\
63 \\
52\end{array}$ & $\begin{array}{c}10.1 \\
6.6 \\
10.8 \\
8.8\end{array}$ & $\begin{array}{l}8.0 \\
5.0 \\
8.1 \\
8.1\end{array}$ & $\begin{array}{r}10.4 \\
6.9 \\
11.5 \\
15.4\end{array}$ & $\begin{array}{l}7.8 \\
5.7 \\
8.5 \\
9.8\end{array}$ \\
\hline Total $(\mathrm{N}=973)$ & 39.2 & 10.5 & 59.3 & 9 & 7.7 & 12 & 9.1 \\
\hline
\end{tabular}


began after the current job was started, (iii) symptoms lasted for more than one week or occurred at least once a month within the past year; (iv) symptoms were reported as "moderate" (the midpoint) or worse on a five-point intensity scale. We did not exclude accidents or sudden injuries related to work from the cases if they met the other requirements for fulfilling the case definition. The case definition was developed by an internal NIOSH ergonomics medical team and has been used in other NIOSH studies on work-related musculoskeletal disorders $(1,4-6$, 10).

\section{Work sampling}

To corroborate self-reports of computer keyboard use, 80 randomly selected participants, 40 with workrelated musculoskeletal disorders of the hand or wrist and 40 referents (with no neck or upper extremity symptoms) participated in the work-sampling evaluation. Employees chosen for the job sampling completed short questionnaires supplying information about usual job tasks and whether the observed day was "typical." Four different job evaluators, blinded to the case status, observed three to five participants over the course of the workshift. The job evaluators recorded the workers' tasks in summaries for 15-min intervals, attempting to obtain 30 observations per participant. During each observation interval, the job evaluators noted the workers' tasks and recorded whether the task involved computer keyboard typing for the length of that period. At the end of the work shift, a summation was performed on the number of observed 15-min intervals involving computer keyboard typing for each of the participants.

\section{Statistical analysis}

For the psychosocial variables (scales), all multi-item scales from the NIOSH general job-stress instrument were factor-analyzed to confirm that they were unidimensional. Further analyses revealed that all of the scales had acceptable reliability (Cronbach alpha coefficients of interval consistency ranging from 0.6 to 0.9). Sum scores were derived for each psychosocial scale.

An unconditional logistic regression analysis was used to develop models relating the predictor variables to the outcome measures for work-related musculoskeletal disorders in each of the three body areas (ie, neck work-related musculoskeletal disorders, shoulder work-related musculoskeletal disorders, and hand or wrist work-related musculoskeletal disorders). Analyses were done with SAS version 6.03 (11).

The development of regression models proceeded as follows. First, the independent variables were grouped into three sets: (i) work practice and work organization, (ii) demographic and individual factors, and (iii) psychosocial factors. Then, within each set, independent variables were tested individually for a relationship with each of the three outcome measures for work-related musculoskeletal disorders using Student's t-test, an analysis of variance, or the likelihood ratio chi-square test, as appropriate.

Independent variables not showing an association (P>0.10) with outcome measures for the work-related musculoskeletal disorders were excluded from further analyses. With a backward elimination procedure, multiple logistic regression was then used to delete additional variables within set 1 until only variables with $\mathrm{P}$-values of $\leq 0.05$ remained. Next, if any continuous variables remained in the model, their quadratic forms were added, tested simultaneously, and deleted from the model if $P>0.05$. In later models, linear terms were forced into the model until quadratic terms were removed (which eventually occurred in all cases). The process was repeated for cubics if quadratics remained in the model. Two-way interactions among the remaining variables were then added to the model. If the $P$-value was $\leq 0.05$ for the simultaneous test, interactions were removed one at a time as before. Next, the remaining variables in set 2 were added to the set 1 model, and the backward elimination procedure was repeated. The remaining variables in set 3 were then added to the combined set 1 and set 2 model and tested simultaneously to see if $\mathrm{P} \leq 0.05$. If so, backwards elimination was performed with the remaining set 1 and set 2 variables forced into the model. The set 1 and set 2 variables were checked, and if the P-value was $>0.05$ for some variable, that variable was removed from the model. A final check on interactions was made as follows. All two-way interactions with gender were added to the final models and tested simultaneously for significance. (Gender remained in each final model. This test was not significant for any symptom.) Then all other two-way interactions were added to the final models. (This test was also not significant for any symptom.) For all of the variables with multi-item response, odds ratios were derived from the $75-25 \%$ interquartile range difference of the scale sum score (ie, the odds ratio reflects the relative risk of a 75 th percentile score compared with a 25 th percentile score).

\section{Results}

\section{Symptoms}

Three hundred and ninety-five (41\%) of the 973 participating employees reported significant work-related symptoms of the neck, shoulder, elbow, or hand or wrist in the last year. In addition, in the previous year, 419 employees reported some symptoms that did not meet our definition of work-related musculoskeletal disorders (figure 1). Table 2 lists the resulting prevalences of the work-related musculoskeletal disorders (participants could report symptoms in more than one body area) and the percentage of cases which reported daily pain in the affected areas. 
Table 2. Prevalences of symptoms of work-related musculoskeletal disorders, as determined by a questionnaire.

\begin{tabular}{|c|c|c|c|c|c|}
\hline \multirow[t]{2}{*}{$\begin{array}{l}\text { Location of } \\
\text { symptoms }\end{array}$} & \multirow{2}{*}{$\begin{array}{c}\text { Persons responding } \\
\text { to the pertinent } \\
\text { part of the } \\
\text { questionnaire }\end{array}$} & \multicolumn{2}{|c|}{$\begin{array}{l}\text { Persons fulfilling } \\
\text { case criteria }\end{array}$} & \multicolumn{2}{|c|}{$\begin{array}{c}\text { Persons fulfilling } \\
\text { case criteria and } \\
\text { experiencing pain } \\
\text { daily }\end{array}$} \\
\hline & & $\mathrm{N}$ & $\%^{a}$ & $\mathrm{~N}$ & $\%$ \\
\hline $\begin{array}{l}\text { Neck } \\
\text { Shoulder } \\
\text { Elbow } \\
\text { Hand or wrist }\end{array}$ & $\begin{array}{l}825 \\
894 \\
939 \\
891\end{array}$ & $\begin{array}{r}214 \\
153 \\
98 \\
199\end{array}$ & $\begin{array}{l}26 \\
17 \\
10 \\
22\end{array}$ & $\begin{array}{l}47 \\
31 \\
30 \\
38\end{array}$ & $\begin{array}{l}22 \\
20 \\
31 \\
19\end{array}$ \\
\hline
\end{tabular}

a Due to the nonproportional sampling, the percentages in this column are not necessarily unbiased estimates of the percentages in this newspaper establishment.

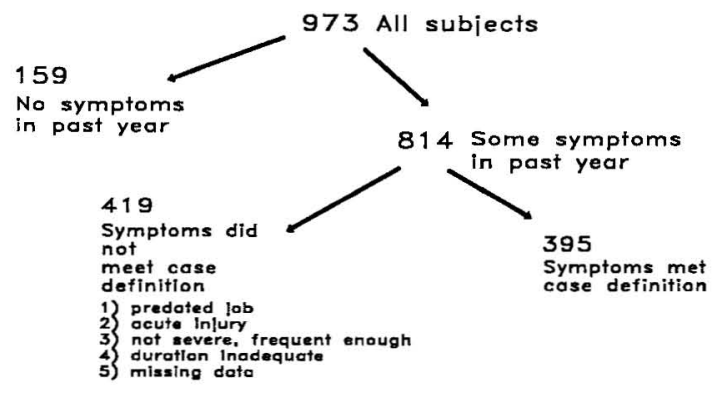

Figure 1. Distribution of musculoskeletal symptoms.

Neck symptoms (26\%) were the most frequently reported, followed by hand or wrist symptoms (22\%), shoulder symptoms (17\%), and elbow symptoms $(10 \%)$. Of those reporting significant symptoms, at least one-third had seen a health care provider, from 10 to $20 \%$ had missed one workday because of the disorder, and 6 to $10 \%$ had been assigned to a different job for one workday due to symptoms.

\section{Predictors of work-related musculoskeletal disor- ders}

Table 3 describes the final logistic regression models relating personal, job characteristic, and psychosocial variables to the three musculoskeletal disorders (neck, shoulder, and hand or wrist areas). (The odds ratios in table 3 for shoulder symptoms were adjusted for race, which remained in the final model, but was felt to be a surrogate for some other variable.)

Individual characteristics. The women were found to be at higher risk than the men for neck (OR 2.1), shoulder (OR 2.2), and hand or wrist (OR 1.7) symptoms (table 4). Because recent studies have suggested that, when men and women have comparable jobs, no gender difference in symptoms is found $(1,12)$, we reanalyzed the final models for each body area, (neck, shoulder, and hand or wrist), restricting the data to those from subjects who worked in jobs with comparable numbers of men and women. These jobs
Table 3. Risk factors in the final logistic regression models for musculoskeletal symptoms in the neck, the shoulders, and the hand or wrist. $(95 \% \mathrm{Cl}=95 \%$ confidence interval)

\begin{tabular}{|c|c|c|}
\hline Location of symptom occurrence & $\begin{array}{l}\text { Odds } \\
\text { ratio }\end{array}$ & $95 \% \mathrm{Cl}^{\mathrm{a}}$ \\
\hline \multicolumn{3}{|l|}{ Neck } \\
\hline Female gender & 2.1 & $1.4-2.4$ \\
\hline $\begin{array}{l}\text { Number of hours spent under } \\
\text { a deadline per week }(30-39 \mathrm{~h} \\
\text { versus } 0-10 \mathrm{~h})\end{array}$ & 1.7 & $1.4-3.0$ \\
\hline $\begin{array}{l}\text { Work variance (eg, continually } \\
\text { changing work load) (occasionally } \\
\text { versus often) }\end{array}$ & $1.7^{\mathrm{b}}$ & $1.2-2.5$ \\
\hline $\begin{array}{l}\text { Time spent on the telephone } \\
(4-6 \text { h versus } 0-2 \mathrm{~h})\end{array}$ & 1.4 & $1.0-1.8$ \\
\hline $\begin{array}{l}\text { Perceived lack of importance for } \\
\text { ergonomic issues by management } \\
\text { (disagree versus agree) }\end{array}$ & $1.9^{b}$ & $1.4-2.4$ \\
\hline \multicolumn{3}{|l|}{ Shoulders } \\
\hline Female gender & 2.2 & $1.5-3.3$ \\
\hline $\begin{array}{l}\text { Perceived lack of participation in } \\
\text { job decision making (very little } \\
\text { versus moderate amount) }\end{array}$ & $1.6^{\mathrm{c}}$ & $1.2-2.1$ \\
\hline $\begin{array}{l}\text { Number of years employed } \\
\text { at the newspaper }\end{array}$ & $1.4^{\mathrm{c}}$ & $1.2-1.8$ \\
\hline $\begin{array}{l}\text { Perceived increased job pressure } \\
\text { (moderately disagree versus } \\
\text { moderately agree) }\end{array}$ & $1.5^{\mathrm{c}}$ & $1.0-2.2$ \\
\hline \multicolumn{3}{|l|}{ Hand or wrist } \\
\hline $\begin{array}{l}\text { Number of hours spent typing } \\
\text { per day }(6-8 \mathrm{~h} \text { versus } 0-2 \mathrm{~h})\end{array}$ & 2.5 & $1.6-3.9$ \\
\hline Female gender & 1.7 & $1.2-2.4$ \\
\hline $\begin{array}{l}\text { Number of hour spent on } \\
\text { deadline per week }(30-39 \mathrm{~h} \\
\text { versus } 0-10 \mathrm{~h})\end{array}$ & 1.6 & $1.2-2.3$ \\
\hline $\begin{array}{l}\text { Perceived lack of support from } \\
\text { an immediate supervisor (very } \\
\text { much versus a little) }\end{array}$ & $1.4^{\mathrm{c}}$ & $1.2-2.5$ \\
\hline \multicolumn{3}{|c|}{$\begin{array}{l}\text { a Confidence intervals derived from the Wald test may be wider } \\
\text { than those derived from the likelihood ratio test, and thus } \\
\text { may include } 1.0 \text {. } \\
\text { b Odds ratio derived from the comparison of the high quartile } \\
\text { to the low quartile of the responses for each scale. } \\
\text { Odds ratios derived from the } 75-25 \% \text { interquartile range } \\
\text { difference of the responses for each scale. }\end{array}$} \\
\hline
\end{tabular}

were found only in the Editorial Department. The results of this analysis (table 4 ) revealed that the odds ratios for the gender variable from the models in the three body areas were not much different from those 
of the original models. However, the results did not remain statistically significant. In fact, most of the variables in the models had odds ratio confidence intervals which included one (the variables "hours spent under a deadline" and "perceived lack of importance for ergonomic issues by management" for work-related musculoskeletal disorders of the neck and the "number of hours spent typing" for workrelated musculoskeletal disorders of the hand or wrist did not).

Neither age nor height were found to be associated with any of the work-related musculoskeletal disorders. Other individual factors (including existing medical conditions or hours spent typing away from work) were not found to be significant predictors.

Job characteristics. The only significant job history risk factor was the number of years employed at the newspaper, which was associated with shoulder symptoms (OR 1.4) (table 3). Of the 17 job-task and work-organization variables, the number of hours spent under a deadline was found to be an important predictor for neck (OR 1.7) and hand or wrist work-related musculoskeletal disorders (OR 1.6) (table 3). Seventy-one percent of the employees reported working under a deadline, $47 \%$ of those with deadlines reporting $0-10$ deadline hours per week and $21 \%$ of those with deadlines reporting more than $30 \mathrm{~h}$ per week under a deadline.

The risk of a work-related musculoskeletal disorder of the hand or wrist increased in a dose-response fashion as the number of hours typing increased (table 5 ). For the $23 \%$ of the participants who reported typing $6-8 \mathrm{~h}$ a day, the OR was 2.1 when they were compared with a reference group (who typed 0 to $2 \mathrm{~h}$ a day). For those with more than $8 \mathrm{~h}$ of typing ( $2 \%$ of the participants) the OR was 3.3 in a comparison with the reference group.

Time spent on the telephone (the only significant work practice variable) had a modest, but significant, association with work-related musculoskeletal disorders of the neck (OR 1.4). Other work practice and work organization factors, including number of breaks (brief or long), number of times arising from a chair, typing skill (slow, medium, or fast), typing technique ("hunt and peck" or touch), use of eyeglasses, or training in posture technique, were not significant predictors.

Psychosocial work environment characteristics. A significantly higher prevalence of work-related musculoskeletal disorders of the neck (table 3 ) was seen for those employees who reported an increased workload variability (OR 1.7) and perceived a lack of importance given to ergonomic issues by management (OR 1.9). The employees with a perceived lack of support from their immediate supervisors tended to have a higher prevalence of work-related musculoskeletal disorders of the hand or wrist (OR 1.4) (ta-
Table 4. Final logistic regression models for work-related musculoskeletal symptoms in the neck, the shoulders, and the hand or wrist in the analysis of jobs having a comparable num. ber of men and women $(\mathrm{N}=150) .(95 \% \mathrm{Cl}=95 \%$ confidence interval)

\begin{tabular}{|c|c|c|}
\hline Location of symptom occurrence & $\begin{array}{l}\text { Odds } \\
\text { ratio }\end{array}$ & $95 \% \mathrm{Cl}$ \\
\hline \multicolumn{3}{|l|}{ Neck } \\
\hline Female gender & 1.9 & $0.8-4.5$ \\
\hline $\begin{array}{l}\text { Number of hours spent under } \\
\text { a deadline per week }(30-39 \mathrm{~h} \\
\text { versus } 0-10 \mathrm{~h})\end{array}$ & 2.8 & $1.1-7.1$ \\
\hline $\begin{array}{l}\text { Work variance (eg, continually } \\
\text { changing work load) (occasionally } \\
\text { versus often) }\end{array}$ & 2.4 & $0.9-6.9$ \\
\hline $\begin{array}{l}\text { Time spent on the telephone } \\
(4-6 \mathrm{~h} \text { versus } 0-2 \mathrm{~h})\end{array}$ & 1.2 & $0.4-3.9$ \\
\hline $\begin{array}{l}\text { Perceived lack of importance for } \\
\text { ergonomic issues by management } \\
\text { (disagree versus agree) }\end{array}$ & 2.3 & $1.1-4.5$ \\
\hline \multicolumn{3}{|l|}{ Shoulders } \\
\hline Female gender & 1.5 & $0.5-4.8$ \\
\hline $\begin{array}{l}\text { Perceived lack of participation in } \\
\text { job decision making (very little } \\
\text { versus moderate amount) }\end{array}$ & 1.8 & $0.7-4.9$ \\
\hline Number of years employed & 1.4 & $0.8-2.5$ \\
\hline $\begin{array}{l}\text { Perceived increased job pressure } \\
\text { (moderately disagree versus } \\
\text { moderately agree) }\end{array}$ & 1.7 & $0.5-6.0$ \\
\hline \multicolumn{3}{|l|}{ Hand or wrist } \\
\hline $\begin{array}{l}\text { Number of hours spent typing } \\
\text { per day }(6-8 \mathrm{~h} \text { versus } 0-2 \mathrm{~h})\end{array}$ & 4.4 & $1.2-15.9$ \\
\hline Female gender & 1.7 & $0.8-3.6$ \\
\hline $\begin{array}{l}\text { Number of hours spent under } \\
\text { a deadline per week }(30-39 \mathrm{~h} \\
\text { versus } 0-10 \mathrm{~h})\end{array}$ & 1.6 & $0.7-3.5$ \\
\hline $\begin{array}{l}\text { Perceived lack of support from } \\
\text { an immediate supervisor (very } \\
\text { much versus a little) }\end{array}$ & 1.5 & $0.6-3.5$ \\
\hline
\end{tabular}

Table 5. Odds ratio of hand or wrist disorders by hours of computer use. ( $95 \% \mathrm{Cl}=95 \%$ confidence interval)

\begin{tabular}{lccc}
\hline $\begin{array}{l}\text { Number of } \\
\text { typing hours }\end{array}$ & $\begin{array}{c}\text { Number } \\
\text { of workers }\end{array}$ & $\begin{array}{c}\text { Adjusted } \\
\text { odds ratio }\end{array}$ & $95 \% \mathrm{Cl}$ \\
\hline 0 to $<2$ (referents) & 177 & 1.0 & \\
2 to $<4$ & 181 & 1.0 & $0.6-1.8$ \\
4 to $<6$ & 244 & 1.3 & $0.8-2.2$ \\
6 to $<8$ & 187 & 2.1 & $1.3-3.6$ \\
$\geq 8$ & 20 & 3.3 & $1.2-8.9$ \\
\hline
\end{tabular}

ble 3). A higher prevalence of shoulder work-related musculoskeletal disorders (table 3 ) occurred for employees who reported a lack of participation in job decision-making (OR 1.6) and increased job pressure (OR 1.5).

Other psychosocial variables - such as job control, worker participation, job security, and interaction with co-workers or customers, group conflict, and lack of social support from spouses and friends - were not found to be significant predictors of work-related musculoskeletal disorders. 
Table 6. Self-reported typing hours versus observed typing hours for the workers with a work-related musculoskeletal disorder of the hand or wrist and the referents.

\begin{tabular}{|c|c|c|c|c|c|c|c|}
\hline \multirow[t]{2}{*}{ Category } & \multirow[t]{2}{*}{$N$} & \multicolumn{2}{|c|}{$\begin{array}{c}\text { Reported } \\
\text { hours of typing }\end{array}$} & \multicolumn{2}{|c|}{$\begin{array}{c}\text { Observed } \\
\text { hours of typing }\end{array}$} & \multirow{2}{*}{$\begin{array}{l}\text { Pearson's } \\
\text { correlation } \\
\text { coefficient }\end{array}$} & \multirow{2}{*}{$\begin{array}{l}\text { Students t-test } \\
\text { (analysis of } \\
\text { observed time } \\
\text { typing) }\end{array}$} \\
\hline & & Mean & $S D$ & Mean & SD & & \\
\hline \multirow{2}{*}{$\begin{array}{l}\text { Workers with } \\
\text { hand symptoms }\end{array}$} & & & & & & & \\
\hline & 36 & 4.5 & 2.6 & 2.5 & 1.4 & 0.39 & $\begin{array}{c}\mathrm{P}<0.022 \\
\mathrm{t}=-2.33 \\
\mathrm{df}=74\end{array}$ \\
\hline Referents & 40 & 3.9 & 2.1 & 1.9 & 0.9 & 0.40 & \\
\hline
\end{tabular}

\section{Work sampling results}

Work sampling was performed for 36 randomly selected persons with hand or wrist symptoms and 40 randomly selected referents. Four selected cases refused to participate. Based on questionnaire data, the mean number of hours typing was $4.5 \mathrm{~h}$ for the symptomatic persons and $3.9 \mathrm{~h}$ for the referents, a significant difference $(\mathrm{P}<0.05)$. For the observed number of hours spent typing, the means were $2.5 \mathrm{~h}$ for the symptomatic persons and $1.9 \mathrm{~h}$ for the referents (table 6). The Student's t-test analysis of the observed times revealed that the symptomatic persons spent significantly more time typing than the referents $(\mathrm{P}<0.02)$. The Pearson correlation coefficients for the observed and reported times were 0.39 for the symptomatic persons and 0.40 for the referents $(\mathbf{P}<0.05)$.

\section{Discussion}

\section{Prevalence}

Approximately $40 \%$ of the newspaper employees reported moderate to severe symptoms which fulfilled our case definition for a work-related musculoskeletal disorder in the neck or upper extremities. Neck symptoms were the most prevalent, followed by hand or wrist, shoulder, and elbow symptoms. The predominance of work-related musculoskeletal disorders in the different upper-extremity areas were similar to the results of previous newspaper VDT surveys (3, written communication, Sauter et al 1981), symptoms in the neck and shoulder (usually combined in most studies) occurring more frequently than in the hand or wrist region. This ranking by upper extremity area was also similar to the results of most previous VDT studies. In a comparison of the hand or wrist results with those newspaper studies which focused only on work-related musculoskeletal disorders of the hand or wrist, the findings were similar, with prevalences in the 17 to $26 \%$ range (table 7 ). It is important to note that only one-third of those with work-related musculoskeletal disorders sought health care; this finding may be related to issues of severity or to an unwillingness to seek care for a myriad of reasons.

\section{Typing hours}

The odds for having a work-related musculoskeletal disorder of the hand or wrist increased in a doseresponse fashion as the number of hours typing increased, with a greater than twofold risk for those typing more than $6 \mathrm{~h}$. Other studies have examined typing hours as a risk for work-related musculoskeletal disorders and found conflicting results (15-19). Factors such as small sample sizes $(18,20)$, which may have lacked statistical power to detect real differences among the groups, or inadequate variance of computer time (10) to account for differences may

Table 7. Newspaper cross-sectional symptom surveys. (NIOSH = National Institute for Occupational Safety and Health, $\mathrm{VDT}=$ video display terminal)

\begin{tabular}{|c|c|c|}
\hline Author & Participants & Identified risk factors and comments \\
\hline NIOSH, $1979(13)$ & 48 VDT users, 29 nonusers & $\begin{array}{l}\text { VDT users with increased arm or hand pain compared with } \\
\text { nonusers; } 48 \% \text { response rate }\end{array}$ \\
\hline Sauter et al, 1981 (35) & 122 VDT users, editorial staff & $19 \%$ with sore wrists within month of survey \\
\hline NIOSH, $1982(14)$ & 379 employees & $\begin{array}{l}\text { Significant association between axial (neck, shoulder, back) } \\
\text { pain and stiffness and current VDT usage }\end{array}$ \\
\hline $\begin{array}{l}\text { Nishuyama et al, } 1983 \\
\text { (3) }\end{array}$ & 437 VDT users, 122 nonusers & $\begin{array}{l}17 \% \text { "duliness in arms"; } 15 \% \text { "dullness in fingers" compared } \\
\text { with } 12 \% \text { and } 5 \% \text {, respectively, of nonusers }\end{array}$ \\
\hline Rempel et al, 1987 (2) & 136 VDT employees & $\begin{array}{l}63 \% \text { response rate; } 26 \% \text { lower arm tendinitis or carpal tunnel } \\
\text { syndrome }\end{array}$ \\
\hline $\begin{array}{l}\text { NIOSH, } \\
\text { University of Michigan, } \\
1990 \text { (1) }\end{array}$ & 834 employees & $\begin{array}{l}40 \% \text { symptoms of work-related musculoskeletal disorders; } \\
\text { percentage of time typing and being a reporter, significant factors }\end{array}$ \\
\hline Buckle, $1992(22)$ & 356 employees & $26 \%$ symptomatic, majority hand or wrist, deadlines important \\
\hline
\end{tabular}


have been responsible for the conflicting results in the cross-sectional studies. Comparisons of typing hours in studies before the mid-1980s may also have been problematic because of differences in VDT equipment at that time (slower equipment, only nonroutine tasks performed on computers) and less reliance on a VDT to complete work tasks by the newspaper work force than in recent years.

Our findings concur with those of another recent NIOSH study (1), which also found an increased risk of work-related musculoskeletal disorders with increasing time spent typing at computer keyboards in VDT work on a newspaper. A follow-up in 1991 at the same newspaper (21) found a significant relationship in the prevalence of work-related musculoskeletal disorders of the hand or wrist on the basis of the percentage of time keying. Despite these recent findings, controversy still remains as to whether a causal relationship exists between the time spent typing on computer keyboards and a greater likelihood of developing musculoskeletal symptoms. Our results support a dose-response relationship; that is, the more hours one spends typing per day, the higher the odds are of developing work-related musculoskeletal disorders of the hand or wrist.

Through job sampling, we observed that the randomly selected persons with hand or wrist symptoms spent significantly more time typing than the randomly selected referents $(P<0.05)$. It has been suggested that VDT users with musculoskeletal symptoms might overestimate their time spent typing as compared with those without symptoms. Although both the symptomatic persons and the referents reported that their average daily typing time was about twice the amount they were observed to type during a single workshift, the degree of overreporting was similar in both groups (table 6). This finding verifies that the symptomatic persons were not overestimating the time spent typing when compared with the referents. These work sampling results concur with results from the recent NIOSH study (1) which found that news reporters with symptoms of workrelated musculoskeletal disorders did not overreport in a comparison with those without such symptoms.

\section{Deadlines}

The results also showed that the number of hours spent working under a deadline was associated with an increased risk of developing work-related musculoskeletal disorders of the hand or wrist. Fifty-three percent of the participants reported $10 \mathrm{~h}$ or more per week under a deadline. More hours under a deadline may contribute to the development of symptoms through multiple mechanisms. For example, increased deadline work may mean greater psychological stress and increased musculoskeletal tension, or simply more exposure to VDT use, such as increased typing and repetition, time in constrained postures, and fewer rest breaks. In his study of journalists using a VDT, Buckle (22) also found that deadline hours, particularly among those journalists facing daily deadlines, predicted the extent and severity of reported pain and discomfort.

\section{Gender}

The analyses revealed that the women were at a higher risk of experiencing symptoms of work-related musculoskeletal disorders. Because the proportions of women and men in the different newspaper jobs varied, we examined the possibility that gender may have been a surrogate for job title. This analysis (tables 5-7) found results similar to those of our original models; however, the results were not significant. The smaller sample size (approximately 150 compared with about 1000 in the full data set) may have reduced the statistical power substantially. Although this result may indicate that gender was not a surrogate for job title in the models based on the complete data, it does not give a clear answer.

The importance of gender as a risk factor for workrelated musculoskeletal disorders has also been controversial. Earlier studies $(23,24)$ have reported that female gender was an important risk factor for carpal tunnel syndrome, but these studies did not look at occupational risk factors, and they did not evaluate men and women performing similar jobs. In a few studies that did concern men and women performing comparable jobs, no gender difference was found $(1,25)$. On the other hand, a recent NIOSH study (10) of VDT users found that in jobs with similar proportions of men and women, female gender was also a risk factor for musculoskeletal symptoms.

It has been suggested that gender may be a surrogate for other important factors, such as a differing set of social stressors for women and different (more stressful) nonoccupational upper extremity usage than men, especially that related to child care and housekeeping (26). Because nonoccupational factors were not examined in detail in this study, it is possible that the gender differences noted may result from confounding from nonoccupational stressors or job factors such as job title, as previously mentioned.

\section{Psychosocial and work organizational factors}

Variables corresponding to increased work-load demands (eg, increased time working under a deadline and increased job pressure) were associated with increased neck, shoulder, and hand or wrist disorders. Lack of support from immediate supervisors and upper management were important factors for work-related musculoskeletal disorders of the neck and the hand or wrist. Overall, our results provide additional evidence that aspects of the psychosocial environment, especially variables corresponding to work or time pressures, lack of social support, and lack of participation in decision making, are important contributors to work-related musculoskeletal disorders 
among office workers. Several studies of office personnel have related relatively high levels of worker stress to work-related musculoskeletal disorders of the upper extremities $(9,27-32)$. In this study, the logistic regression models showed psychosocial factors to be more influential in predicting musculoskeletal disorders in the neck and shoulder regions than in the hand or wrist area.

The causal linkages between a demanding psychosocial environment at work and symptoms of workrelated musculoskeletal disorders are not well understood, but several plausible mechanisms can be postulated. Psychosocial demands resulting in job stress may increase the awareness (and possibly overreporting) of musculoskeletal symptoms or may affect perceptions of their cause (ie, increased attribution to the workplace). In addition, stressful work conditions may be associated with more physically (ie, biomechanically) demanding situations or may produce increased muscle tension and consequent biomechanical strain as caused by stress-induced static muscle loads in the neck and shoulders $(33,34)$.

Such factors as lack of control over many aspects of the job, increased isolation, reduction of task diversity, and increased work load have been attributed to the introduction of VDT workstations into the workplace and to the increase in reports of work-related musculoskeletal disorders $(35,36)$.

\section{Limitations}

A high response rate (93\%), minimizing the potential for selection bias, was obtained in the study. Inherent in this type of study is the potential for "survivor bias" (ie, not including people who left their jobs because of the health problems of interest). This possibility may result in an underestimation of an association between risk factors and health problems. However, survivor bias was not considered to be a major problem in this study, since both records and accounts of newspaper employees indicate that the number of individuals who left the work force during the year preceding the study was small.

Because risk factors and health problems are measured at the same time in cross-sectional studies, it is not always possible to determine which occurred first. For example, an important association was found between hand or wrist symptoms and lack of support by the immediate supervisor, but we were unable to ascertain whether symptoms or the perceived lack of support came first.

Because the prevalence rates for work-related musculoskeletal disorders were determined solely by selfreported symptoms from questionnaires, the prevalence of work-related disorders could have been over- or underestimated. However, our rates agree fairly well with those in prior research $(1,2)$. No reference group outside the newspaper industry was studied, and therefore it is unclear whether there are certain characteristics (such as frequent deadlines) which put newspaper employees at increased risk for symptoms when compared with other computer users. In addition, musculoskeletal symptoms are fairly common in the general population and may arise from nonoccupational activities. Therefore, it is not possible to determine precisely the proportion of all the disorders which are work-related.

This study did not fully address the impact of variables that are not work-related and their possible associations with work-related musculoskeletal disorders. For example, we did address social support issues of spouses, friends, and relatives, but we did not cover issues such as child care or home responsibilities, which may have some impact on the occurrence of neck and upper extremity symptoms (25).

Because the analysis in this study included a variable reduction scheme, it is possible that some of the variables from the questionnaire were not included in any final model because of their elimination in an intermediate stage, when perhaps they could conceivably have attained a $P$-value of $\leq 0.05$ when all three sets were combined. Therefore, a possibility of "false negatives" exists, and variables not included in the final models should not be confused by the reader with a definite statement of "no-effect."

In a study that examines numerous potential associations between possible exposure factors (like work pressure or hours of typing) and multiple different health outcomes, it is likely that a few of the associations are "statistically significant" by chance alone and are thus spurious. Differentiating spurious and nonspurious associations is a difficult task involving an examination of observed effects in light of past findings, determining biological plausibility, and considering the strength of associations. However, recurring associations confirmed by others (such as the relationship between typing under a deadline and work-related musculoskeletal disorders of the hand or wrist) are not as likely to be spurious.

\section{Concluding remarks}

Despite the inherent limitations, this study provides additional evidence that increased work load or job pressures and hours of computer use are related to the occurrence of work-related musculoskeletal disorders, particularly for symptoms in the hand or wrist area. This study also supports the conclusion that work-related musculoskeletal disorders among newspaper employees is dependent on a variety of factors, among them job task, work organization, and psychosocial factors. An approach to the prevention of work-related musculoskeletal disorders among these employees, which systematically includes all these elements, has the greatest likelihood of being successful in reducing the magnitude and severity of work-related musculoskeletal disorders. The jobsampling conducted by us documents that there was no selective overreporting of time spent typing by 
those employees with symptoms in a comparison with those without symptoms (response bias). Finally, psychosocial factors appear to be more important risk factors for neck and shoulder disorders than for hand or wrist disorders in relation to work.

Overall, the physical and psychosocial associations identified in this study are consistent with findings of similar studies. However, the modest strength of the associations between each individual predictor and health outcome measure suggests that a substantial reduction in symptom rates may be difficult to achieve. Nevertheless, prevention efforts cannot wait until the etiology of work-related musculoskeletal disorders is completely understood. Effective prevention intervention may shed more light on the complex web of causal factors than any other type of action.

\section{References}

1. National Institute for Occupational Safety and Health (NIOSH). NIOSH health hazard evaluation report: Newsday, Inc, Melville, New York. Cincinnati, OH: US Department of Health and Human Services, Public Health Service, Centers for Disease Control, National Institute for Occupational Safety and Health, 1990. NIOSH report no HETA $89-250-2046$.

2. Rempel D, Lopes J, Davila R, Davis B. Cumulative trauma among visual display terminal users at a newspaper company. Berkeley, CA: Hazard Evaluation System and Information Service, Department of Health Services, 1987.

3. Nishuyama K, Nakaseko M, Uehata T. Health aspects of VDT operators in the newspaper industry. In: Grandjean E, editor. Ergonomics and health in modern offices. Philadelphia, PA: Taylor and Francis, 1983:113-8.

4. National Institute for Occupational Safety and Health (NIOSH). NIOSH heath hazard evaluation 89-251-.. 1997: Cargill Poultry Division, Buena Vista, Ga. Cincinnati, OH: US Department of Health and Human Services, Public Health service, Center for Disease Control, National Institute for Occupational Safety and Health, 1990. NIOSH report no 89-251-1997, NTIS report no $\mathrm{PB}-90-183-989$,.

5. National Instrtute for Occupational Safety and Health (NIOSH). NIOSH health hazard evaluation report: John Morrell \& Co, Sioux Falls, South Dakota. Cincinnati, OH: US Department of Health and Human Services, Pubiic Health Service, Centers for Disease Control, National Instrtute for Occupational Safety and Health, 1990. NIOSH report no HETA 88-1801958.

6. National Institute for Occupational Safety and Health (NIOSH). NIOSH health hazard evaluation report: Shoprite Supermarkets, New Jersey-New York. Cincinnati, OH: US Department of Health and Human Services, Public Health Service, Centers for Disease Control, National Institute for Occupational Safety and Health, 1990. NIOSH report no HETA 88-3442092.

7. Hurrell $\mathbf{J} J \mathbf{J} r$, McLaney M. Exposure to job stress a new psychometric instrument. Scand J Work Environ Health 1988;14 suppl 1:27-8.

8. Lindström K, Hurrell JJ Jr. Coping with job stress by managers at different career stages in Finland and the United States. Scand J Work Environ Health 1992;18 suppl 2:14-7.

9. McLaney MA, Hurrell JJ Jr. Control stress and job sat- isfaction in Canadian nurses. Work Stress 1992;2(3): $217-24$.

10. National Institute for Occupational Safety and Health (NIOSH). NIOSH health hazard evaluation report: US WEST Communications, Phoenix, Az, Minneapolis, Mn, Denver, Co. Cincinnati, OH: US Department of Health and Human Services, Public Health Service, Centers for Disease Control, National Institute for Occupational Safety and Health, 1992. NIOSH report no HETA 89-299-2230.

11. SAS Institute Inc. SAS guides for personal computers. Release 6.03 Edition. Cary, NC: Sas Institute Inc, 1988.

12. Franklin GM, Haug J, Heyer N, Checkoway H, Peck N. Occupational carpal tunnel syndrome in Washington State, 1984-1988. Am J Public Health 1991; $81(6): 741-46$.

13. National Institute for Occupational Safety and Health (NIOSH). Report of a cross-sectional survey of video display terminal users at the Baltimore Sun, Baltimore, Maryland. Cincinnati, OH: United States Department of Health and Human Services, Public Health Service, Centers for Disease Control, NIOSH, 1979. Report, no PB83-195149.

14. National Institute for Occupational Safety and Health (NIOSH). Potential health hazards of video display terminal: a NIOSH research report. Cincinnati, OH: United States Department of Health and Human Services, Public Health Service, Centers for Disease Control, NIOSH, 1982. Report, no 81-129.

15. Jeyaratnam J. Musculoskeletal disorders among VDU operators - an Asian perspective. In: Luczak $\mathrm{H}$, Çakir AE, Çakir G, editors. Proceedings of the third international scientific conference on work with display units. Berlin: Papyrus-Druck GmbH Publishers, 1992:D-1.

16. Sauter S, Gottlieb M, Rohrer K, Dodson V. The wellbeing of video display terminal users, an exploratory study 210-79-0034. Cincinnati, OH: University of Wisconsin and Centers for Disease Control, National Institute for Occupational Safety and Health, US Department of Health and Human Services, 1983.

17. Hocking B. Epidemiological aspects of "repetitive strain injury" in Telecom Australia. Med J Aust 1987; $147(5): 218-22$.

18. DeMatteo R, Denton M, Hayward L. Musculoskeletal disorders among data entry operators. In: Luczak $\mathrm{H}$, Çakir AE, Çakir G, editors. Proceedings of the third international scientific conference on work wrth display units. Berlin: Papyrus-Druck GmbH Publishers, 1992:D-44.

19. Franzblau A, Flaschner D, Aibers JW, Blitz S, Werner R, Armstrong T. Medical screening of office workers for upper extremity cumulative trauma disorders. Arch Environ Health 1993;48(3):164—70.

20. De Krom MCTF, Kester ADM, Knipschild PG, Spaans F. Risk factors for carpal tunnel syndrome. Am J Epidemiol 1990:132(6): 1102-10.

21. Silverstein B. Prevalence of work-related musculoskeletal disorder symptoms in newspaper employee: follow-up survey summary. In: Armstrong T, editor. Proceedings of the international conference on occupational disorders of the upper extremities. Ann Arbor, MI: University of Michigan, Center for Occupational Health and Safety Engineering, 1992.

22. Buckle P. Work related upper limb disorders amongst journalists. In: Armstrong T, editor. Proceedings of the international conference on occupational disorders of the upper extremities. Ann Arbor, MI: University of Michigan Center for Occupational Health and Safety Engineering, 1992:1-8.

23. Massey EW. Carpal tunnel in pregnancy. Obstet Gynecol Surv 1978;33:145-8.

24. Sabour M, Fadel H. The carpal tunnel syndrome: a 
new complication ascribed to the pill. Am J Obstet Gynecol 1970;107:1265-7.

25. Franklin GM, Haug J, Heyer N, Checkoway H, Peck N. Occupational carpal tunnel syndrome in Washington State, 1984-1988. Am J Public Health 1991; 81(6):741-6.

26. Bergqvist U, Aronsson G. VDU work - do women experience more musculoskeletal problems than men? In: Luczak H, Çakir AE, Çakir G, editors. Proceedings of the third international scientific conference on work with display units. Berlin: Papyrus-Druck $\mathrm{GmbH}$ Publishers, 1992:D-45.

27. Sauter SL, Swanson NG. The effects of frequent rest breaks on performance and well-being in repetitive VDT work. In: Luczak H, Çakir AE, Çakir G, editors. Proceedings of the third international scientffic conference on work with display units. Berlin: PapyrusDruck GmbH Publishers, 1992:D-52.

28. Stellman JM, Klitzman S, Gordon G, Snow BR. Comparison of well-being among non-machine interactive clerical workers and full-time and part-time VDT users and typists. In: Knave B, Wideback P, editors. Proceedings of the international conference on work with display units. Amsterdam: Elsevier Publishers BV, 1987:605-13.

29. Wallace M, Buckle P. Ergonomics aspects of neck and upper limb disorders. In: Osborne DJ, editor. International review in ergonomics: current trends in human factors research and practice, vol 1. London: Taylor and Francis, 1987:173-200.

30. Linton SJ, Kamwendo K. Risk factors in the psychosocial work environment for neck and shoulder pain in secretaries. J Occup Med 1989;31(7):609-13.

31. Gao C, Lu D, She O. The effects of VDT data entry work on operators. Ergonomics 1990;33(7):917-24.

32. Evans J. Women, men, VDU work and health: a questionnaire survey of British VDU operators. Work Stress 1987;1(3):271-83.

33. Hagberg M, Sundelin G. Discomfort and load on the upper trapezius muscle when operating a word processor. Ergonomics 1986;29:1637-45.

34. Aronsson G, Bergqvist U, Almers A. Work organization and musculoskeletal discomfort in VDT work. Stockholm: Arbetarskyddsverket, 1992. Arbete och hälsa, no 4:1992.

35. Sauter SL, Harding GE, Gottlieb MS. VDT-computer automation of work practices as a stressor in information-processing jobs: some methodological considerations. In: Salvendy G, Smith MJ, editors. Proceedings of the international conference on machine pacing and occupational stress. London: Taylor and Francis Ltd, 1981:355-60.

36. Bammer $G$. How technologic change can increase the risk of repetitive motion injuries. Semin Occup Med 1987;2(1):25-30.

Received for publication: 1 December 1993 